\title{
Two New Species of Acritarchs From the Ordovician of Iraq
}

Amer D. Nader

\author{
Nazar A. Al-Mola
}

Department of Geology

College of Science

University of Mosul

(Received 2/1/2012, Accepted 13/2/2012)

\section{ABSTRACT}

Two new distinctive species of acritarchs belonging to genus Fractoricoronula are described from strata of Late Ordovician Epoch in borehole Khleisia-1 in Iraq. These are Fractoricoronula densa sp.nov. and Fractoricoronula khabouri sp.nov.

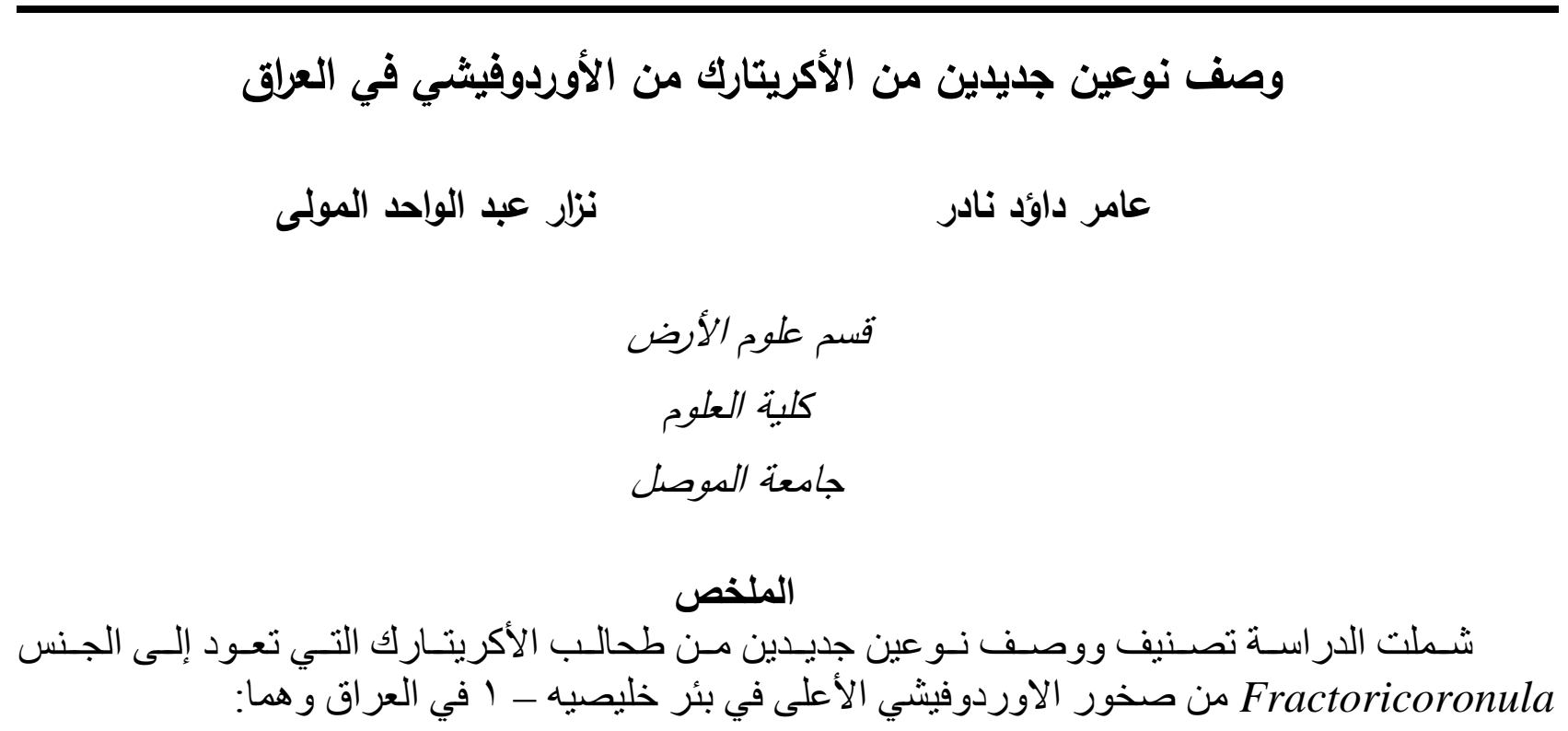

Fractoricoronula khabouri sp.nov. و Fractoricoronula densa sp.nov.

\section{INTRODUTION}

The oldest rock unit exposed in northern Iraq is the Ordovician Khabour Formation which crops out in narrow limited zone in the core of Ora, Chalki and Kaista anticlines in north and northwestern Amadia district (Bellen et al., 1959). In the western side of Iraq the oldest rock unit exposed is the Ga'ara Formation (Late Carboniferous - Permian) in the Ga'ara depression.

Due to the limited outcrops exposure the information about the Paleozoic Formations were obtained from the deep wells, which drilled in the area between Khleisia and Mosul city and the studied well is one of these (Fig. 1). The studied 
samples were collected from borehole Khleisia-1, which is located at $35^{\circ} 1921.3^{\prime \prime} \mathrm{N}, 41^{\circ} 3818^{\prime \prime} \mathrm{E}$ at Khleisia anticline northwestern Iraq, the total depth of the well is $(3791.4 \mathrm{~m}$.) and the studied section is between depths $(3400.0-2543.5 \mathrm{~m})$ penetrating Khabour Formation (Fig. 2).

The Paleozoic sedimentary strata fall into three characteristic major sedimentary cycles, separated by relatively major breaks, indicating the effects of the Caledonian and Hercynian orogeneses. One of these cycles is the Cambrian - Ordovician (?Silurian) cycle represented in Iraq mainly by the Khabour Formation (Buday, 1980).

Bellen et al., 1959 and other earlier authors included the Pirispiki Red Beds and Chalki Volcanics in this cycle (Buday, 1980). Seilacher, 1963 in Buday, 1980 proved that Pirispiki Red Beds and Chalki Volcanics belong to the next cycle (Devonian Lower Carboniferous) cycle and were deposited after the Caledonian uplifted.

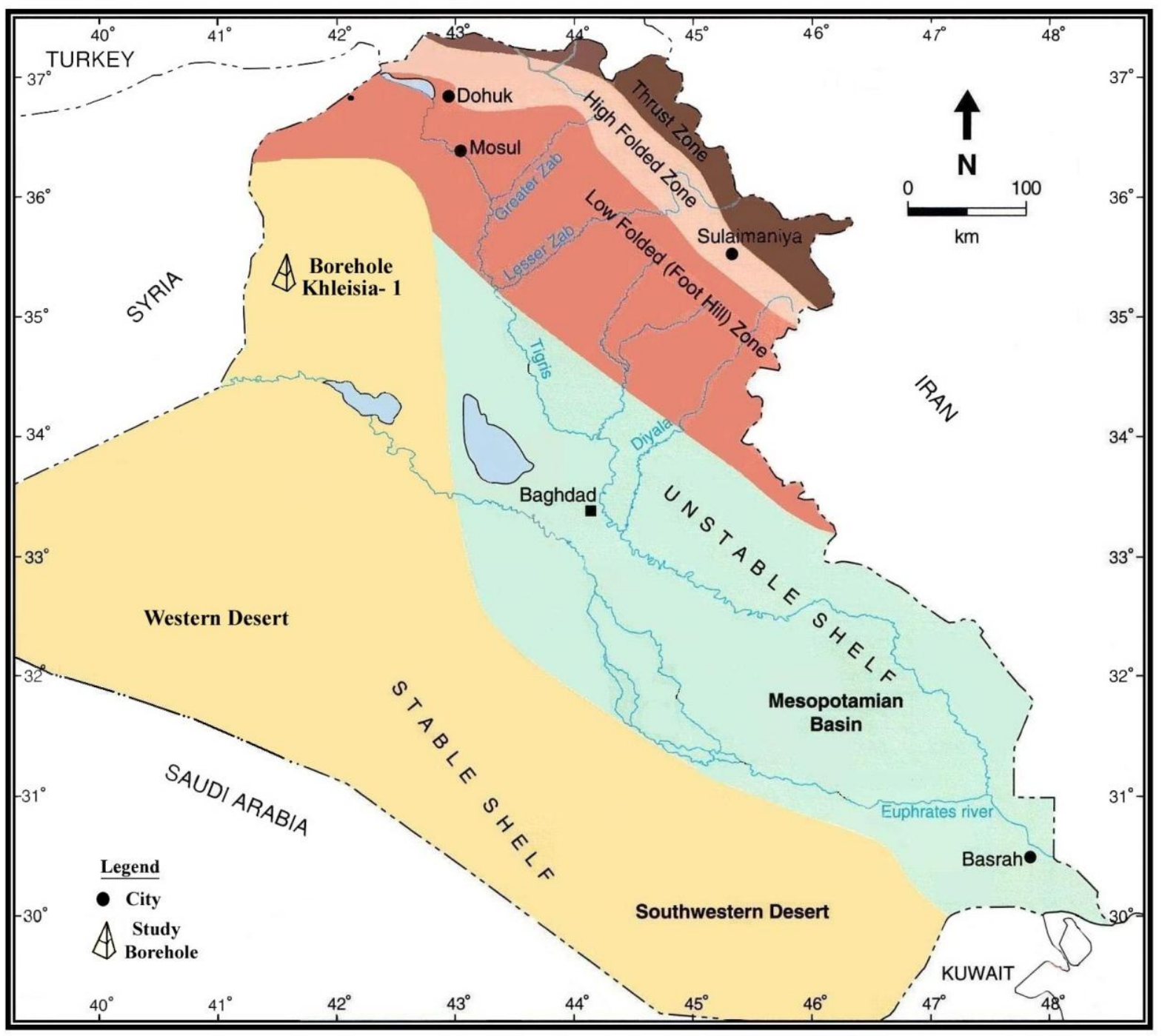

Fig. 1. Locality Map Showing the Location of the Studied borehole Khleisia - 1 . 


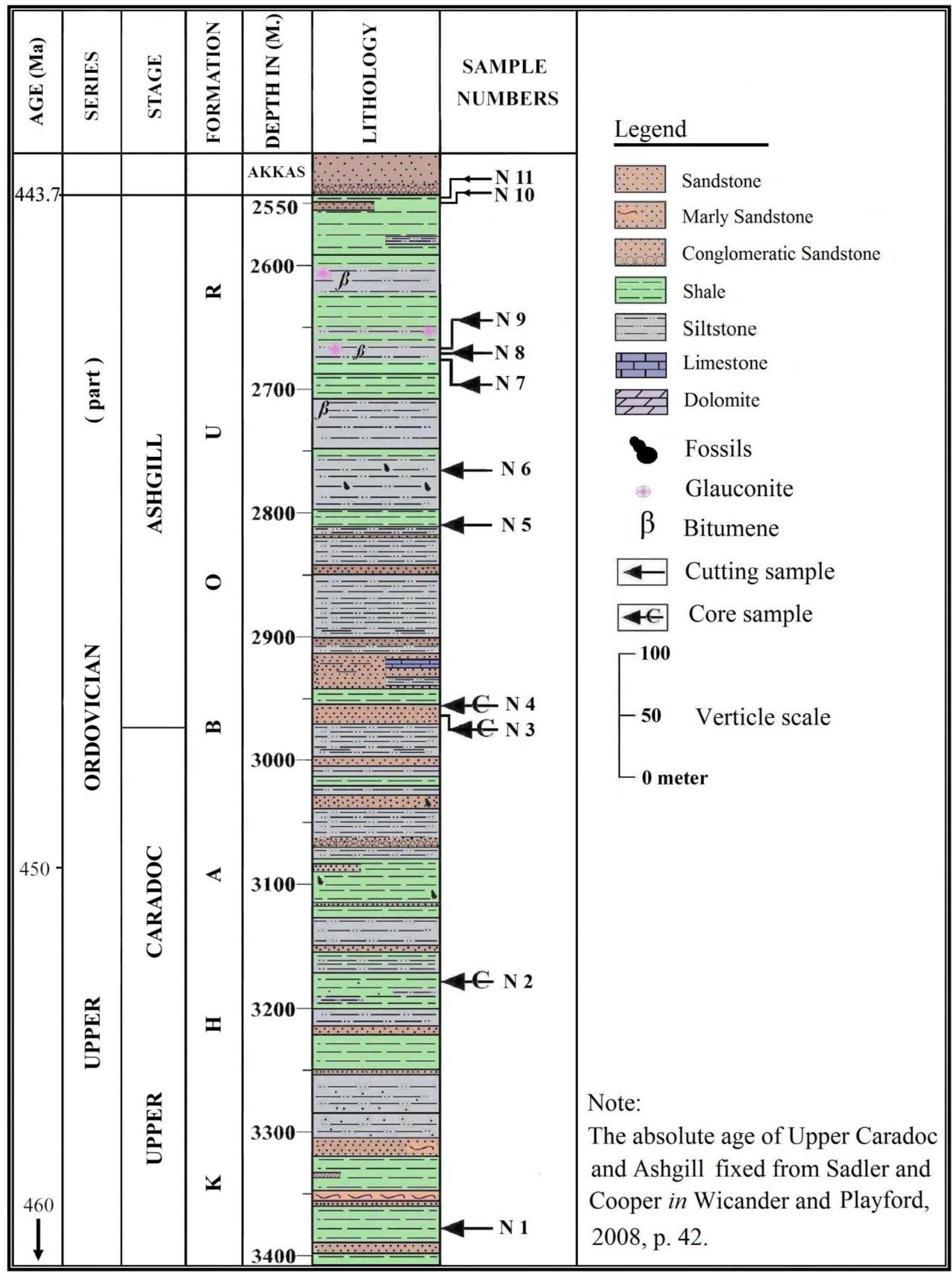

Fig. 2: The Studied Stratigraphic Succession of Borehole Khleisia -1 . 


\section{STRATIGRAPHY}

The Khabour Formation was first defined by Wetzel, 1950 in van Bellen et al., 1959 in the northern thrust zone, which named after the Khabour river in the vicinity of Amadia district, north of Iraq. The exposed part of the type section is $(800 \mathrm{~m})$ thick (base not reached). The outcrop portion of the Formation is purly clastic composed of thin bedded, fine grained sandstone and silty micaceous shale (Buday, 1980) (Fig. 2).

According to the palynological study the Khabour Formation was deposited in the inner-middle shelf, under low energy water (Al-Mola, 2009).

\section{MATERIAL AND METHODS}

Eleven samples were taken from Iraqi Exploration Oil Company representing depths (3400.0-2543.5m), these samples have been treated with the standard method in preparing palynological samples by adding $\mathrm{HCl}$ to dissolve carbonates, $\mathrm{HF}$ to dissolve silicates and with $\mathrm{HNO} 3$ to oxidize organic matters from the samples.

\section{SYSTEMATIC PALYNOLOGY}

INCERTAE SEDIS

Informal Group ACRITARCHA Evitt, 1963

Genus Fractoricoronula Colbath, 1979 emend. Turner, 1984

Type species: Fractoricoronula cubitalia Colbath, 1979, p.15, pl. 5, Figs.1-5, (by original designation)

Fractoricoronula densa sp. nov.

$$
\text { Pl.1, Figs.1- }
$$

2009 Genus A Al-Mola p.109-110, pl. 21, Figs.11-16, pl.22, Figs.1-4.

\section{DESCRIPTION}

Vesicle triangular, sides straight to convex, angles rounded, three processes arise from the vesicle, one process at each angle in the plain of vesicle, processes conical, flexible, the proximal side of the process is closed by inner wall or plug $(2-3 \mu \mathrm{m})$ 
length and $(2.5-5 \mu \mathrm{m})$ wide, the processes terminated with acuminated tip. The vesicle wall is $(3 \mu \mathrm{m})$ thick while the processes wall $(1 \mu \mathrm{m})$ in thickness, both walls are laevigate. Excystement structure is observed in some specimens as epityche between any two processes.

Holotype: Depth (2766.0 m.), slide number (N6), Fig.1, R 1.5/128.7, size $45 \mu \mathrm{m}$.

\section{COMPARISON}

This species is differed from $F$. cubitalia Colbath, 1979 by it is thicker vesicle wall and smooth ornament for both vesicle and processes wall and from $F$. trirbetica Turner, 1984 by the process length (which is less than the vesicle length), conical shape and thicker vesicle wall.

\section{MEASURMENTS}

\begin{tabular}{|c|c|c|c|}
\hline $\begin{array}{c}\text { Vesicle size } \\
\text { in }(\mu \mathrm{m})\end{array}$ & $\begin{array}{c}\text { Process length } \\
\text { in }(\mu \mathrm{m})\end{array}$ & $\begin{array}{c}\text { Width of process base } \\
\text { in }(\mu \mathrm{m})\end{array}$ & Specimens measured \\
\hline $28-49$ & $16-45$ & $2.5-5$ & 27 \\
\hline
\end{tabular}

Name Derivation: Greek densa, thick.

\section{Fractoricoronula khabouri sp. nov.}

Pl.1 Figs.7-9

2009 Genus A Al-Mola, p.110, pl.22, Figs. 5-7.

\section{DESCRIPTION}

Vesicle triangular, sides straight, angles rounded, three processes arise from the triangular angles in the plain of vesicle, the forth process arises from the vesicle face near one of the angles, processes conical and flexible, the proximal side of the process is closed by inner wall or plug $(2-3 \mu \mathrm{m})$ length and $(2.5-5 \mu \mathrm{m})$ wide, the processes terminated with acuminated slender tip.

The vesicle wall is $(2-3 \mu \mathrm{m})$ and the processes wall $(1 \mu \mathrm{m})$ in thickness, both walls are laevigate. No excystement structure is observed.

Holotype: Depth (2810.30m.), slide number (N5), Fig.7, R 6.0/133.8, size $43 \mu \mathrm{m}$. 


\section{COMPARISON}

This species is distinguished from Fractoricoronula densa sp. nov. in having fourth process arising from the vesicle surface.

\section{MEASURMENTS}

\begin{tabular}{|c|c|c|c|}
\hline $\begin{array}{c}\text { Vesicle size } \\
\text { in }(\mu \mathrm{m})\end{array}$ & $\begin{array}{c}\text { Process length } \\
\text { in }(\mu \mathrm{m})\end{array}$ & $\begin{array}{c}\text { Width of process base } \\
\text { in }(\mu \mathrm{m})\end{array}$ & Specimens measured \\
\hline $43-47$ & $21-45$ & $3-4$ & 5 \\
\hline
\end{tabular}

Name Derivation: Khabouri after the Khabour river.

\section{PLATE 1}

Coordinates given are for the Olympus $\mathrm{BH} 2$ photograph with slide label on the left unless the coordinates are prefixed by $\mathrm{R}$ when the slide label is on the right.

1- Fractoricoronula densa, Holotype, N6, 2766.00m., R1.5/128.7, size45 $\mu \mathrm{m}$.

2- F. densa, N5, 3.6 / 132.6, size $49 \mu \mathrm{m}$.

3- F. densa, N8, R 9.1 / 131.1, size $43 \mu \mathrm{m}$.

4- F. densa, N3 ${ }^{1}, \mathrm{R} 5.2$ / 125.2, size $40 \mu \mathrm{m}$.

5- F. densa, $\mathrm{N}^{2}, 9.9$ / 126.8, size $45 \mu \mathrm{m}$.

6- F. densa, N9, 10.4 / 121.2, size $43 \mu \mathrm{m}$.

7- F. Khabouri, Holotype, N5, 2810.30m., R 6.0/133.8, size $43 \mu \mathrm{m}$.

8- F. Khabouri, N6, 5.9 / 122.5, size $44 \mu \mathrm{m}$.

9- F. Khabouri, N2, 4.2 / 106.7, size $47 \mu \mathrm{m}$. 


\section{Plate (1}
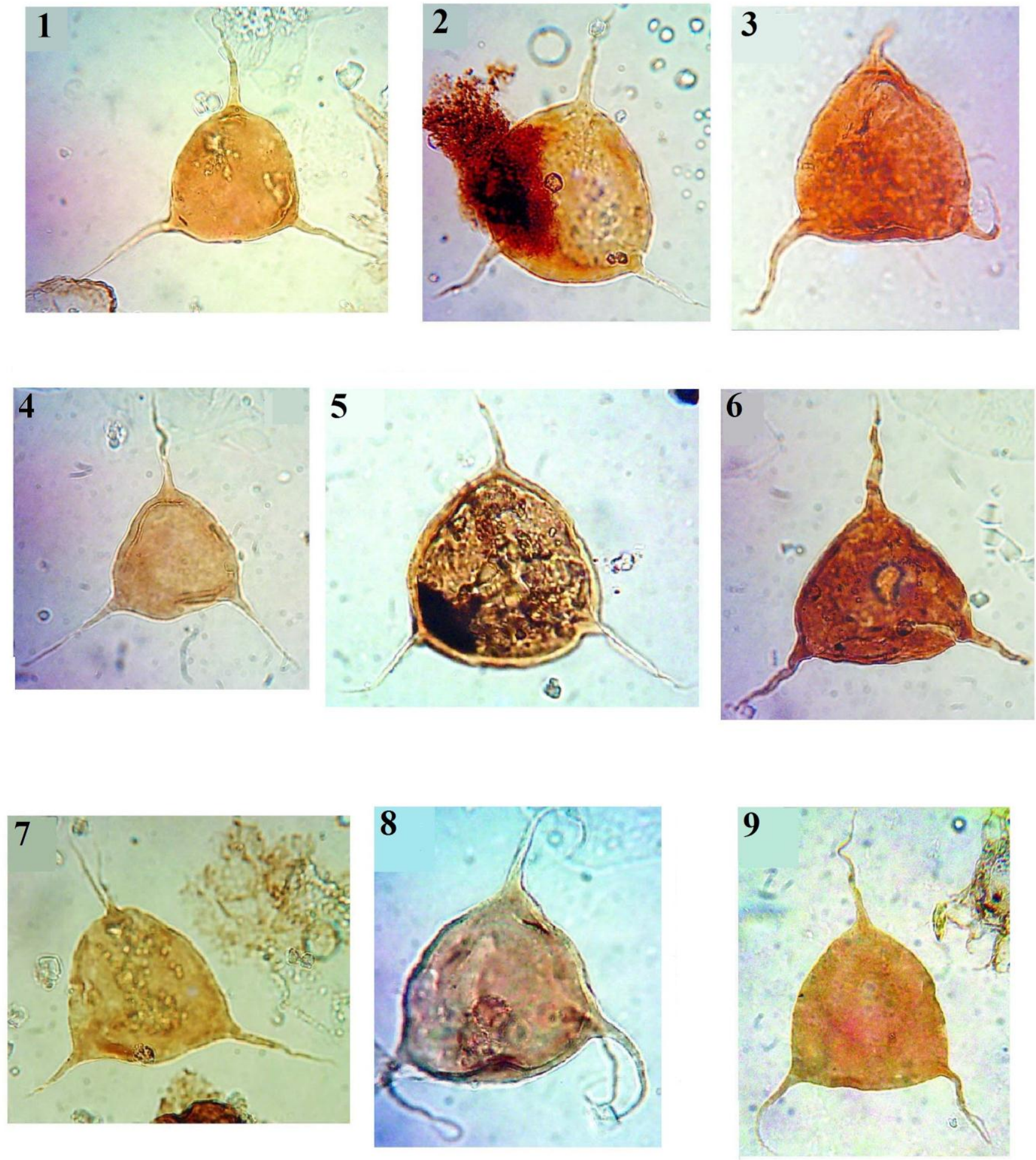


\section{REFERENCES}

Al-Mola, N. A. M., 2009. Study of The Upper Ordovician Acritarchs from Khabour Formation in Borehole Khleisia -1, NW Iraq. Unpublished Ph.D. Thesis, University of Mosul. Iraq. 139 p. (in Arabic with English Abstract).

Bellen, R. C. Van., Dunnington, H. V., Wetzel, R. and Morton, D. M., 1959. Lexique Stratigraphique International, Vol. III: Asie, Paris Center National Recherche Scientifique Fasc. 10a, Asia, Iraq, 333 p.

Buday, T., 1980. The Regional Geology of Iraq. Stratigraphy and Paleogeography. Dar. Al-Kutub Publication House., Mosul, Iraq, 445 p.

Colbath, G. K., 1979. Organic-walled Microphytoplankton from the Eden Shale (Upper Ordovician), Indiana, U.S.A. Palaeontographica, Abt. B, Vol. 171, No. 1 - 3, pl. 1 - 14, pp. 1 - 38.

Turner, R. E., 1984. Acritarchs from the Type Area of the Ordovician Caradoc Series, Shropshire, England. Palaeontographica, Abt.B, Vol. 190, pp. 87 - 157. 